\title{
MEMAKNAKAN FUNGSI UNDANG-UNDANG DASAR SECARA IDEAL DALAM PEMBENTUKAN UNDANG-UNDANG
}

\author{
Ricca Anggraeni \\ Fakultas Hukum, Universitas Pancasila \\ Jln. Srengseng Sawah, Jakarta Selatan, 12640 \\ riccaanggraeni@univpancasila.ac.id
}

\begin{abstract}
As the basic rule of state governance, the Constitution of the Republic of Indonesia 1945 contains the legal norm that is the basis for the establishment of an operational platform for the objectives and idealsof Indonesian can be achieved. In other words, the legal norm contained in the basic articles of law is a stake for the Indonesian regulatory system. The crucial role of the Constitution, is not possible for the legislation to rely on the legacy ratio to be disconnected from understanding the meaning of the legal norm of the Constitution itself. Just case, in practice political compromise tends to be the main focus for pouring the legal norm. This is to enter the problem for the misconceptualation of the Indonesian legislation system.
\end{abstract}

Keywords: Constitution; Political Compromise; Legislation; System of Legislation

\begin{abstract}
Abstrak
Sebagai aturan dasar atau pokok penyelenggaraan negara, tentu Undang-Undang Dasar Negara Republik Indonesia Tahun 1945 memuat norma hukum yang menjadi dasar bagi pembentukan landasan operasional agar tujuan dan cita hukum negara Indonesia dapat tercapai. Dengan kata lain, norma hukum yang terkandung dalam pasal-pasal Undang-Undang Dasar menjadi tiang pancang bagi sistem peraturan perundang-undangan di Indonesia. Peran Undang-Undang Dasar yang krusial, sangat tidak memungkinkan bagi pembentuk Undang-Undang atau peraturan perundang-undangan untuk mengandalkan ratio legis yang terputus dari pemahaman makna knstruksi norma hukum Undang-Undang Dasar itu sendiri. Hanya saja, dalam praktiknya kompromi politik cenderung menjadi tumpuan utama untuk menuangkan norma hukum dalam Undang-Undang Dasar di Undang-Undang. Inilah yang diyakini sebagai pembuka pintu masalah bagi miskonsepsinya sistem peraturan perundang-undangan di Indonesia.
\end{abstract}

Keywords: Undang-Undang Dasar; Kompromi Politik; Undang-Undang; Sistem Peraturan Perundang-Undangan

\section{A. Pendahuluan}

Berpijak pada data jumlah pengajuan judicial review atas Undang-Undang terhadap Undang-Undang Dasar di Mahkamah Konstitusi, kajian ini sampai pada dugaan, serendah itukah kualitas Undang-Undang. Lalu, bagaimana dampaknya bagi peraturan pelaksana dan peraturan otonom yang menjadikan Undang-Undang (diajukan judicial review) itu sebagai dasar atau sumber pembentukannya. Artinya, stabilitas sistem peraturan perundang-undangan akan sering terganggu, jika Undang-Undang yang menjadi dasar atau sumber pembentukan diajukan 
judicial review kemudian diputuskan bertentangan dengan Undang-Undang Dasar dan dinyatakan tidak mempunyai kekuatan hukum mengikat.

Jumlah putusan atas judicial review Undang-Undang terhadap Undang-Undang Dasar, berdasarkan website https://mkri.id/index.php?page=web.RekapPU $\underline{\mathrm{U} \& m e n u=4}$ dari tahun 2003 sampai dengan tahun 2019 sudah mencapai 1258 (seribu dua ratus lima puluh delapan). Dari jumlah itu, hasil putusan yang dikabulkan sebanyak 261 (dua ratus enam puluh satu). Dengan demikian, pemikiran sederhananya ialah bahwa putusan MK yang berjumlah 261 itu akan mempengaruhi sistem peraturan perundang-undangan.

Oleh karena itu, penting untuk mengkaji mengenai konsistensi, koherensi dan korespondensi antara Undang-Undang dengan Undang-Undang Dasar. Sebagai aturan dasar atau pokok negara, menurut Hans Nawiasky merupakan aturan-aturan yang masih bersifat pokok dan merupakan aturan umum yang masih bersifat garis besar dengan norma yang masih merupakan norma hukum tunggal. Aturan dasar negara dapat dituangkan dalam suatu dokumen negara yang dikenal dengan Staatsverfassung atau dalam beberapa dokumen negara yang disebut dengan Staatsgrundgesetz. Sebagai aturan dasar atau pokok negara, berfungsi sebagai landasan bagi pembentukan Undang-Undang dan peraturan lain yang lebih rendah (Indrati, 2007).

Konstitusi atau Undang-Undang Dasar juga dianggap sebagai kerangka kehidupan politik suatu negara yang di dalamnya mengatur tentang kehidupan bernegara yang memperluas partisipasi politik, memberi kekuasaan legislatif kepada rakyat, serta menolak kekuasaan yang otoriter (Santoso, 2013). Dalam pengertian konstitusi yang diberikan oleh Brian Thompson, dapat dilihat bahwa konstitusi merupakan suatu aturan untuk menjalankan suatu organisasi yang disebut negara. Ini tidak jauh berbeda apabila memahami konstitusi dari pengertiannya secara etimologis, yaitu pernyataan untuk membentuk, menyusun suatu Negara (Suhardjana, 2010).

Dengan pemahaman tersebut, disadari betul bahwa Undang-Undang Dasar memiliki peranan sentral di dalam penyelenggaraan negara. Bahkan, Undang-Undang Dasar merupakan titik pijak bagi politik hukum yang akan bertanggung jawab melahirkan sistem hukum nasional untuk mencapai tujuan negara. Dikatakan sebagai titik pijak bagi politik hukum dan sistem hukum nasional, karena Undang-Undang Dasar sebagai dokumen yang menentukan penyelenggaraan negara, tidak hanya terdiri dari pasal-pasal yang tertuang dalam batang tubuh, melainkan juga pembukaan yang di dalamnya tertuang tujuan dan cita negara, bahkan landasan filosofis negara Indonesia, yaitu Pancasila.

Politik hukum sendiri menurut Mahfud Md., diartikan sebagai arah kebijakan hukum dari lembaga, badan atau pejabat yang memiliki kewenangan untuk membentuk peraturan. Melalui politik hukum pula, ditambahkan oleh Mahfud Md, sebuah produk hukum dalam bentuk peraturan perundangundangan dapat dikritisi dan dievaluasi mengenai kesesuaiannya dengan tujuan Negara (Mahfud Md, 2012). Artinya dengan politik hukum, dapat dibentuk dan dipengaruhi sistem hukum nasional yang digunakan untuk mencapai tujuan negara, bahkan untuk menentukan isi dari peraturan sebagai salah satu wujud dari suatu kebijkan.

Sistem hukum nasional bukanlah suatu sistem yang berdiri bebas merdeka tanpa terpengaruh oleh unsur lain di dalam suatu negara, melainkan tempat saling bergantungnya banyak komponen untuk menentukan sistem hukum, diantaranya isi peraturan, lembaga-lembaga, kesadaran hukum dan perilaku masyarakat, sarana termasuk di dalamnya sumber daya manusia, perkembangan informasi dan teknologi 
bahkan pendidikan tinggi hukum (Mahfud Md, 2012).

Salah satunya yang menentukan sistem hukum nasional ialah isi peraturan. Isi peraturan atau substansi peraturan perundangundangan inilah yang menyusun berbagai peraturan perundang-undangan sebagai suatu sistem. Di dalam pembentukan peraturan perundang-undangan untuk konteks Indonesia harus mengikuti cara atau prosedur yang telah ditetapkan oleh peraturan perundangundangan. Selain itu, sebagai konsekuensi dari negara yang "telah diposisikan" mengkonsepkan hukum sebagai norma, aliran positivisme hukum atau legisme mendarah daging dalam sistem hukum di Indonesia. Oleh karena itu pula, ajaran hukum sebagai kehendak yang dikemukakan oleh John Austin dan teori hukum murni yang dikemukakan oleh Hans Kelsen sangat dimaknai dalam penyusunan sistem perundang-undangan di Indonesia.

Melalui ajaran hukum sebagai kehendak dan teori hukum murni Hans Kelsen, peraturan perundang-undangan di Indonesia dibentuk. Jadi, pijakan dibentuknya norma hukum dalam peraturan perundang-undangan di Indonesia ialah berdasarkan kehendak dari penguasa, yang dalam hal ini diartikan sebagai lembaga/badan atau pejabat yang memiliki kewenangan. Selain itu, juga berpijak pada ajarannya Hans Kelsen, bahwa pembentukan norma hukum itu bersumber dan berdasar pada norma yang yang lebih tinggi, demikian seterusnya sampai pada suatu norma yang tidak dapat ditelusuri lebih lanjut dan bersifat hipotetis dan fiktif yaitu norma dasar atau Grundnorm (Indrati, 2007).

Artinya, apabila mengikuti ketentuan Pasal 7 Undang-Undang Nomor 12 Tahun 2011 tentang Pembentukan Peraturan Perundang-undangan yang mengatur tentang jenis dan hierarki peraturan perundangundangan di Indonesia, maka yang menjadi dasar atau sumber pembentukan seluruh norma hukum di Indonesia ialah Undang-
Undang Dasar Negara Republik Indonesia Tahun 1945. Mengingat, Undang-Undang Dasar lah yang menduduki puncak hierarki dari jenis norma hukum peraturan perundangundangan di Indonesia.

Dikarenakan itulah, sekali lagi dinyatakan bahwa Undang-Undang Dasar memiliki peran sentral di dalam penyelenggaraan negara. Undang-Undang Dasar sebagai pijakan dibentuknya seluruh norma hukum peraturan perundang-undangan di Indonesia, yang menjadi landasan operasional bahkan landasan teknis pengambilan kebijakan. Oleh karena itu, sangat tidak memungkinkan bagi pembentuk Undang-Undang atau peraturan perundang-undangan untuk mengandalkan ratio legis yang terputus dari pemahaman makna konstruksi norma hukum UndangUndang Dasar itu sendiri, karena itu yang harus mengalir ke seluruh norma hukum di dalam sistem peraturan perundang-undangan di Indonesia.

Pembukaan dan pasal-pasal dalam batang tubuh Undang-Undang Dasar Negara Republik Indonesia Tahun 1945, itulah yang dikonkretisasikan serta dioperasionalkan melalui undang-undang dan peraturan pelaksana serta peraturan otonom. Seharusnya, di dalam pembentukan norma hukum UndangUndang tidak bisa tidak mengembangkan nilai lain selain nilai-nilai yang terkandung di dalam Undang-Undang Dasar, sehingga undang-undang yang dibentuk sebagai panduan penyelenggaraan negara konsistensi, koherensi dan korespondensi dengan UndangUndang Dasar Negara Republik Indonesia Tahun 1945.

Hanya saja dalam praktiknya, kompromi politik di kalangan pembentuk UndangUndang sebagai cerminan dari kehendak penguasa atau lembaga/badan atau pejabat yang memiliki kewenangan cenderung menjadi tumpuan utama untuk menuangkan norma hukum dalam Undang-Undang Dasar di Undang-Undang. Inilah yang diyakini sebagai pembuka pintu masalah bagi miskonsepsinya 
sistem peraturan perundang-undangan di Indonesia.

Miskonsepsi peraturan perundangundangan itulah yang diduga menjadi penyebab banyaknya pengajuan judicial review di Mahkamah Konstitusi. Permasalahan itu terjadi karena memang pembentukan norma hukum peraturan perundang-undangan bersandarkan pada kompromi politik, meskipun berdasar dan bersumber pada norma yang lebih tinggi. Dengan demikian, pertanyaan yang timbul di dalam kajian ini ialah mengenai bagaimanakah seharusnya Batang Tubuh Undang-Undang Dasar berfungsi di dalam pembentukan Undang-Undang, sehingga bersandarkan pada kompromi politik untuk mencapai ksepakatan?

Melalui peminatan terhadap Teori Perundang-undangan, kajian ini ingin menguraikan tentang seharusnya pembentuk Undang-Undang memaknakan fungsi UndangUndang Dasar di dalam pembentukan Undang-Undang, agar dapat terdeteksi solusi mengenai pembenahan sistem peraturan perundang-undangan di Indonesia. Mengingat Undang-Undang merupakan pedoman dalam penyelenggaraan negara.

Melalui kajian ini, dikonstruksikanuraian agar dapat memberikan solusi untuk pembenahan sistem peraturan perundangundangan di Indonesia, sehingga kajian ini terdiri dari 3 (tiga) bagian. Bagian pertama merupakan bagian pendahuluan yang yang didalamnya terdapat permasalahan dari kajian ini. Bagian berikutnya yaitu pembahasan yang menguraikan hasil elaborasi dari doktrin dan pendekatan-pendekatan lain yang digunakan. Bagian terakhir dari penelitian ini simpulan.

\section{B. PEMBAHASAN}

\section{Konstitusi Dalam Konstelasi Sistem Ketatanegaraan Republik Indonesia}

Seperti telah diketahui sebelumnya, bahwa konstitusi merupakan kerangka bangunan pemerintahan dan dokumen yang menjamin hak-hak asasi manusia serta wujud dari kesepakatan masyarakat untuk membina dan mengatur masyarakat. Konstitusi dapat saja diartikan sebagai Undang-Undang Dasar (Rumokoy, 2011). Sri Soemantri bahkan menyatakan bahwa konstitusi atau UndangUndang Dasar pada umumnya berisi 3 (tiga) hal pokok, yaitu: (1) Jaminan terhadap hak asasi manusia dan warga Negara; (2) Ditetapkannya susunan ketatanegaraan suatu negara yang bersifat fundamental; dan (3) Adanya pembagian dan pembatasan tugas ketatanegaraan yang juga bersifat fundamental (Rumokoy, 2011).

Dari pemahaman mengenai konstitusi dan isinya, dapat dinyatakan bahwa memang konstitusi atau Undang-Undang Dasar memuat aturan-aturan pokok tentang penyelenggaraan negara. Melalui itulah dirumuskan berbagai aturan, kaidah yang membangun sistem ketatanegaraan suatu negara.

Berdasarkan hal tersebut, artinya, dari Undang-Undang Dasarlah dapat diketahui konstelasi sistem ketatanegaraan Republik Indonesia. Menyebut Undang-Undang Dasar, sudah harus diketahui bahwa itu merupakan sebagian dari hukum dasarnya Indonesia, karena di samping itu, masih ada hukum dasar lain yang tidak tertulis yang disebut dengan konvensi ketatanegaraan. Dengan kata lain, Undang-Undang Dasar merupakan sumber hukum formil suatu negara yang di dalamnya mengatur tentang masalah ketatanegaraan dan hukum dasar bagi pengembangan peraturan, seperti di Undang-Undang, dan peraturan perundang-undangan lain di bawahnya, bahkan sampai pengambilan kebijakan yang berkaitan dengan kepentingan negara dan masyarakat (Sinamo, 2012).

Sebagai sumber bagi ketatanegaraan Republik Indonesia, Undang-Undang Dasar menjamin perlindungan hukum atas hak-hak asasi anggota masyarakatnya, dan landasan struktural penyelenggaraan pemerintahan untuk mengatur tentang pengelolaan kekuasaan pemerintahan. Ini dapat dilihat dari 
konstruksi sistematika Undang-Undang Dasar Negara Republik Indonesia Tahun 1945.

Sebelumnya, dapat digunakan pendekatan sejarah dari perubahan Undang-Undang Dasar 1945. Pada tahun 1999 sampai dengan tahun 2002, Undang-Undang Dasar telah mengalami empat tahap perubahan. Empat tahap itu telah mengubah hampir keseluruhan materi muatan Undang-Undang Dasar. Dari catatannya Jimly Asshiddiqie, perubahan terhadap naskah asli UUD 1945 telah menghasilkan 199 butir ketentuan dari sebelumnya 71 butir ketentuan. Dari 199 butir ketentuan yang ada dalam UUD 1945, hanya 25 (12\%) butir ketentuan yang tidak mengalami perubahan. Selebihnya, sebanyak 174 (88\%) butir ketentuan merupakan materi yang baru atau mengalami perubahan (Rohi, 2013).

Perubahan yang terjadi secara mendasar tentu membawa perubahan bagi konstelasi sistem ketatanegaraan Republik Indonesia. Pengaruh yang luar biasa terjadi, seperti pada munculnya lembaga-lembaga yang memegang kekuasaan baru, perubahan kewenangan pada Majelis Permusyawaratan Rakyat (MPR), dan menghapus lembaga pemegang kekuasaan yang telah ada, yaitu Dewan Pertimbangan Agung (DPA).

Pengaruh tersebut, misalnya pada lembaga yang memiliki kewenangan di bidang legislasi yaitu Dewan Perwakilan Daerah (DPD). Munculnya DPD dalam sistem ketatanegaraan Republik Indonesia tentu mengubah konstelasi pembentukan UndangUndang di Indonesia. Semula kekuasaan membentuk Undang-Undang dipegang oleh Presiden dengan persetujuan Dewan Perwakilan Rakyat, berubah menjadi dipegang oleh Dewan Perwakilan Rakyat dengan persetujuan bersama Presiden. DPD sebagai lembaga baru memiliki kewenangan untuk mengajukan ke DPR RUU yang berkaitan dengan otonomi daerah, hubungan pusat dan daerah, pembentukan dan pemekaran serta penggabungan daerah, pengelolaan sumber daya alam dan sumber daya ekonomi lainnya, serta yang berkaitan dengan perimbangan keuangan pusat dan daerah. Selain mengajukan RUU, DPD juga memiliki kewenangan untuk membahas dan melakukan pengawasan atas pelaksanaan RUU tersebut.

Pengaruh lainnya ialah pada kekuasaan kehakiman di dalam sistem ketatanegaraan Republik Indonesia. Munculnya, lembaga baru seperti Mahkamah Konstitusi dan Komisi Yudisial mengubah pelaksana kekuasaan kehakiman dari yang semula dilakukan oleh Mahkamah Agung dan badan-badan lain kehakiman menurut Undang-Undang, menjadi dilakukan oleh sebuah Mahkamah Agung dan badan peradilan yang berada di bawahnya dalam lingkungan peradilan umum, peradilan agama, peradilan militer, peradilan tata usaha negara, dan oleh sebuah Mahkamah Konstitusi. Sedangkan Komisi Yudisial hadir dalam sistem ketatanegaraan Republik Indonesia untuk menjaga dan menegakkan kehormatan, keluhuran martabat, serta perilaku hakim.

Pengaruh pereduksian dari kewenangan MPR ialah bahwa MPR tidak lagi berkedudukan sebagai lembaga tertinggi negara, melainkan hanya sebagai lembaga negara, yang menjadi wadah dari anggota DPR dan DPD. MPR hanya memiliki kewenangan untuk mengubah dan menetapkan Undang-Undang Dasar, melantik Presiden dan/atau Wakil Presiden, dan hanya dapat memberhentikan Presiden dan/atau Wakil Presiden dalam masa jabatannya menurut Undang-Undang Dasar. Dari yang semula MPR memiliki kewenangan untuk menetapkan Undang-Undang Dasar dan garisgaris besar ada haluan negara, memilih Presiden dan Wakil Presiden.

Pengaruh lain dari perubahan UndangUndang Dasar Negara Republik Indonesia Tahun 1945 ialah dimuatnya hak asasi manusia, yang semula hanya sedikit pasalpasalnya yang berkaitan dengan HAM. Dari semua pasal yang dimuat dalam UndangUndang Dasar sebelum diubah, tidak akan 
pernah dijumpai pemakaian istilah hak asasi manusia, tetap hak dan kewajiban warga negara. Setelah perubahan Undang-Undang Dasar, pengaturan mengenai HAM dicantumkan dalam satu bab tersendiri yaitu dalam Bab XA yang terdiri dari 10 pasal yaitu dari Pasal 28A sampai dengan Pasal 28J. Rumusan HAM dalam perubahan Undang-Undang Dasarsangat lengkap yang mencakup seluruh aspek HAM secara universal sebagaimana yang tercantum dalam Universal Declaration of Human Rights. Perlu juga dipahami bahwa HAM yang diatur dalam perubahan Undang-Undang Dasar Negara Republik Indonesia Tahun 1945 tidak ada yang bersifat mutlak dan tanpa batas, termasuk HAM yang termuat dalam Pasal 28I ayat (1) Undang-Undang Dasar Negara Republik Indonesia Tahun 1945, meskipunhak itu dikategorikan sebagai hak yang tidak dapat dikurangi dalam keadaan apapun (non derogable rights) yang meliputi hak untuk hidup, hak untuk tidak disiksa, hak kemerdekaan pikiran dan hati nurani, hak beragama, hak untuk tidak diperbudak, hak untuk diakui sebagai pribadi di hadapan hukum, dan hak untuk tidak dituntut atas dasar yang berlaku surut (Handayani, 2014).

Dengan demikian, konstitusi atau Undang-Undang Dasar sebagai bagiannya merupakan aturan tertinggi menurut tata urutan atau hierarki peraturan perundangundangan yang diajarkan oleh Kelsen dan Nawiasky. Isinya yang mengatur tentang jaminan hak asasi manusia, ditetapkannya susunan ketatanegaraan negara dan pembagian dan pembatasan tugas ketatanegaraan membuat Undang-Undang Dasar berfungsi sebagai aturan yang mengatur jalannya organisasi negara. Oleh karena itu, apapun yang dimuat dalam Undang-Undang Dasar sangat mempengaruhi kerangka kerja dari lembaga atau badan penyelenggara kekuasaan negara yang menjadi landasan untuk menjalankan kewenangan dalam penyelenggaraan negara (Suhardjana, 2010).
Itulah sebab, konstitusi atau Undang-Undang Dasar menjadi tiang pancang bagi penyelenggaraan negara yang sangat mempengaruhi konstelasi sistem ketatanegaraan suatu negara.

\section{Sistem Hukum Nasional Kaitannya Dengan Sistem Peraturan Perundang- Undangan Di Indonesia}

Berbicara sistem hukum nasional tidak bisa jauh dari berbagai sub sistem yang saling mempengaruhi dan terkait sehingga membentuk satu kesatuan yang utuh dan teratur (Atmadja, 1984). Sebagai suatu sistem yang mengalir dalam negara bertradisi civil law, tidak dapat dipungkiri bahwa yang menjadi sub sistem paling berpengaruh ialah norma hukum yang tertulis dalam suatu peraturan perundang-undangan. Mengingat, karena memang sumber hukum utama di negara bertradisi civil law ialah UndangUndang (aturan formal).

Berpijak dari deskripsi tersebut, di dalam pembentukan sub-sub sistem yang saling mempengaruhi di dalam sistem hukum nasional, tidak boleh mangkir dari Pancasila yang menjadi Staatsfundamentalnorm (norma dasar) di dalam konsep negara Indonesia. Hal ini penting, agar penyusunan sistem hukum nasional menjadi searah dengan cita dan jiwa bangsa Indonesia. Dengan demikian, pembangunan hukum nasional pun akan memainkan perannya untuk mencapai tujuan negara, seperti yang sudah dirumuskan dalam Undang-Undang Dasar Negara Republik Indonesia Tahun 1945.

Menggunakan pendapatnya Lawrence $\mathrm{M}$. Friedmann mengenai sistem hukum,aturan hukum merupakan salah satu dari tiga unsur sistem hukum lainnya yaitu struktur dan budaya (Yuliandri, 2013). Aturan hukum atau legal substance dalam pemahamannya Satjipto Rahardjo ialah "produk" dari sistem hukum itu sendiri yang diwujudkan dalam norma-norma hukum yang tertuang dalam peraturan dan putusan hakim. Bahkan doktrin pun dapat 
dikategorikan sebagai legal substance dalam pemahamannya Satjipto Rahardjo (Rahardjo, 1980). Agak mirip dengan yang dikatakan oleh Satjipto Rahardjo mengenai substansi hukum yaitu yang diungkapkan oleh Laica Marzuki, bahwa "substansi hukum merupakan seperangkat kaidah hukum yang lazim disebut dengan peraturan perundang-undangan." Tetapi, substansi hukum tidak hanya meliputi pengertian kaidah hukum tertulis tetapi juga kaidah hukum kebiasaan atau tidak tertulis.

Rencana Pembangunan Jangka Panjang Nasional (RPJPN) 2005-2025 pun telah menyebutkan bahwa sistem hukum nasional dapat diwujudkan dengan pembangunan substansi hukum yang sesuai dengan aspirasi masyarakat dan kebutuhan pembangunan, penyempurnaan struktur hukum dan pelibatan seluruh komponen masyarakat yang berkesadaran hokum (Rohi, 2013).

Dengan demikian, seperti telah dinyatakan di awal bahwa dalam civil law system, substansi hukum menjadi sub-sub dari sistem hukum yang menonjol dibandingkan dengan sub-sub sistem yang lain. Pengembangan aturan hukum dalam peraturan perundang-undangan di civil law system menjadi arus utama. Dikarenakan menjadi arus utama, pembentukan peraturan perundang-undangan menjadi pekerjaan yang sulit bagi lembaga legislatif di Indonesia. Unger pun memperingatkan tentang pembentukan norma hukum dalam peraturan perundang-undangan di suatu sistem hukum. Menurut Unger, setiap sistem pembuat hukum akan mencerminkan nilai-nilai sosial-politik tertentu sebagai akibat dari pilihan hukum tertentu dalam menentukan metode hukum tertentu. Dengan kata lain pilihan terhadap metode hukum tertentu akan menghasilkan keputusan hukum yang tertentu pula.

Menurut Unger, hukum tak terpisahkan dari politik dan berbagai norma non-hukum lainnya. Hukum dibentuk oleh berbagai faktor non-hukum seperti kepentingan ekonomi, ras, gender, atau politik dengan mengandaikan interaksi dan negosiasi antar berbagai kelompok masyarakat. Akibatnya hukum akan terisolasi dari konteks sosial-politiknya, jika pendekatannya hanya doktrinal. Ketika hukum terisolasi, maka hukum tidak bisa mengatasi berbagai masalah sosial politik (Danardono, 2015).

Pembentukan hukum dalam konteks peraturan perundang-undangan memegang peranan penting di dalam pembangunan sistem hukum nasional. Mewujudkan sistem hukum nasional yang mampu membawa bangsa Indonesia mencapai cita dan tujuan negaranya diperlukan pembentukan peraturan perundangundangan yang sesuai dengan nilai-nilai yang terkandung dalam Pancasila sebagai norma fundamental negara dan Undang-Undang Dasar Negara Republik Indonesia Tahun 1945 sebagai aturan dasar atau aturan pokok negara. Meskipun dalam realitas empiriknya, interaksi dan negoisasi untuk mencapai kesepakatan dalam menentukan nilai di suatu norma hukum dalam peraturan perundang-undangan.

Melihat sub-sub sistem yang mendukung dan saling terkait di dalam sistem hukum nasional, substansi hukum yang merupakan salah satu sub sistem dapat diartikan sebagai norma hukum peraturan perundang-undangan. Dengan demikian, sistem hukum nasional sangat terkait dengan sistem peraturan perundang-undangan, karena ini yang membentuk satu kesatuan yang utuh di dalam siklus legal substance peraturan perundangundangan di Indonesia. Melalui sistem peraturan perundang-undangan dapat dilihat nilai yang hidup dan konsisten dari perwujudan Pancasila dan Undang-Undang Dasar Negara Republik Indonesia Tahun 1945 sebagai upaya untuk mewujudkan cita dan tujuan negara dari bangsa Indonesia.

\section{Ideal Memaknakan Fungsi Undang- Undang Dasar Di Dalam Pembentukan Undang-Undang}

Seperti yang dinyatakan oleh Mahfud Md, bahwa peraturan perundang-undangan 
merupakan dokumen peraturan negara yang berada di bawah Undang-Undang Dasar (Mahfud Md, 2010). Ini artinya, termasuk Undang-Undang.Dari berbagai jenis peraturan perundang-undangan, dengan mengingat Pasal 7 dan Pasal 8 Undang-Undang Nomor 12 Tahun 2011 tentang Pembentukan Peraturan Perundang-undangan, Undang-Undang merupakan jenis peraturan perundangundangan yang memiliki kelebihan di atas peraturan perundang-undangan yang lain. Hal itu dikarenakan Undang-Undang dibentuk langsung oleh perwakilan rakyat Indonesia yang termanifestasi dalam lembaga Dewan Perwakilan Rakyat, dan dalam pembentukannya memerlukan persetujuan bersama dari Presiden.

Undang-Undang juga merupakan pengaturan lebih lanjut dari berbagai ketentuan yang terdapat dalam UndangUndang Dasar. Artinya, Undang-Undang merupakan landasan operasional yang menjadi penentu bagi pelaksanaan penyelenggaraan negara dan pedoman bagi perilaku masyarakat dalam pergaulan berbangsa dan bernegara.

Seperti diketahui, Undang-Undang Dasar yang merupakan aturan dasar atau aturan pokok negara berbagai aturan yang membangun sistem ketatanegaraan suatu negara. Sebagai aturan dasar atau pokok negara, pun, Undang-Undang Dasar berisi aturan-aturan umum yang masih merupakan norma hukum tunggal, dan berfungsi sebagai landasan bagi pembentukan Undang-Undang dan peraturan lain yang lebih rendah.

Undang-Undang Dasar sebagai bagian dari hukum dasarnya negara, juga dianggap sebagai kerangka kehidupan politik suatu negara atau suatu aturan untuk menjalankan suatu organisasi negara. Dengan pemahaman itu, disadari betul bahwa Undang-Undang Dasar memiliki peranan sentral di dalam penyelenggaraan negara. Bahkan, UndangUndang Dasar menjadi titik pijak bagi politik hukum yang akan bertanggung jawab melahirkan sistem hukum nasional untuk mencapai tujuan negara, karena di dalam Undang-Undang Dasar, tidak hanya terdiri dari pasal-pasal batang tubuh, melainkan juga pembukaan yang di dalamnya tertuang tujuan dan cita negara, bahkan landasan filosofis negara Indonesia, yaitu Pancasila.

Sebagai negara yang lebih mengkonsepkan hukum sebagai norma yang tertuang dalam bentuknya yang pasti yaitu peraturan perundang-undangan, aliran positivisme hukum atau legisme tentu sudah mendarah daging dalam pembentukan sistem hukum di Indonesia. Oleh karena itu, ajaran hukum sebagai kehendak yang dikemukakan oleh John Austin dan Stufenttheorie yang dikemukakan oleh Hans Kelsen sangat dimaknai dalam sistem perundang-undangan di Indonesia, sehingga norma hukum yang lebih tinggi menjadi dasar dan sumber bagi pembentukan norma hukum di bawahnya.Artinya, norma hukum yang lebih rendah hierarkinya mendapatkan aliran dari norma hukum yang lebih tinggi.

Kembali apabila merujuk pada Pasal 7 Undang-Undang Nomor 12 Tahun 2011 yang telah menentukan jenis dan hierarki peraturan perundang- undangan di Indonesia, bahwa Undang-Undang Dasar Negara Republik Indonesia Tahun 1945 yang lebih memiliki kekuatan hukum mengikat berdasarkan tingkatannya, dibandingkan dengan peraturan perundang-undangan lain, sehingga dapat ditemukan jenis peraturan perundangundangan yang menjadi sumber aliran, yaitu Undang-Undang Dasar Negara Republik Indonesia Tahun 1945.

Aliran yang dimaksud dalam kajian ini ialah aliran nilai, sehingga nilai yang terkandung dalam norma hukum yang lebih tinggi terkandung pula di dalam norma yang lebih rendah. Jika, nilai itu dapat dicapai, konsekuensi logisnya ialah, tujuan yang hendak dicapai oleh norma yang lebih tinggi dapat dicapai pula oleh norma yang lebih rendah, sehingga antara norma-norma itu tercipta harmonisasi dalam dinamika untuk 
mencapai tujuan bersama, di dalam sebuah sistem peraturan perundang-undangan. Setiap jenis peraturan perundang-undangan, bahu membahu untuk mewujudkan nilai yang terkandung di dalam Undang-Undang Dasar, sehingga tujuan dan cita negara akhirnya dapat tercapai.

Hal tersebutlah yang menurut Arief Hidayat ialah sebagai politik hukum instrumental atau operasional, sehingga nilainilai di dalam norma-norma hukum peraturan perundang-undangan memiliki konsistensi, koherensi dan korespondensi dengan politik hukum dasar, dalam hal ini ialah UndangUndang Dasar Negara Republik Indonesia Tahun 1945, dan ideal yaitu Pancasila. Hal ini penting, mengingat - pun yang dinyatakan oleh Barda Nawawi Arief bahwa Pancasila merupakan landasan filosofis bagi terbentuknya Politik dan Sistem Hukum Nasional Indonesia, sehingga dalam landasan operasionalnya terbangun, terbina dan terwujud nilai-nilai Pancasila (Arief, 2012). Dengan kata lain, seluruh sistem peraturan perundang-undangan di Indonesia harus secara konsisten mengimplementasikan nilai-nilai dalam Undang-Undang Dasar untuk mengatur penyelenggaraan negara dan kehidupan masyarakat secara luas (Arief, 2008).

Tetapi dalam realitasnya, nilai-nilai itu belum tentu terbangun dan terwujud dalam sistem peraturan perundang-undangan di Indonesia, atau dalam bahasa perundangundangannya ialah sinkronisasi dan harmonisasi tidak teramu dalam suatu sistem, sehingga nilai yang terkandung antara norma yang termuat tidak harmonis dengan nilai yang terkandung dalam Undang-Undang Dasar.

Persoalan tidak harmonisnya kandungan nilai di dalam suatu peraturan perundangundangan, perlu mengingat yang dinyatakan oleh Unger, bahwa setiap sistem pembentuk hukum akan mencerminkan nilai-nilai sosialpolitik tertentu. Oleh karenanya, hukum tak terpisahkan dari politik dan berbagai norma non-hukum lainnya. Hukum dibentuk oleh berbagai faktor non-hukum seperti kepentingan ekonomi, ras, gender, atau politik dengan mengandalkan interaksi dan negosiasi antar berbagai kelompok masyarakat.

Apabila di dalam pembentukan UndangUndang masih didominasi oleh kepentingan tertentu dengan mengandalkan interaksi dan negoisasi untuk mencapai kesepakatan diantara berbagai kelompok masyarakat, maka yang terjadi ialah kemungkinan bertambahnya jumlah pengajuan judicial review atas Undang-Undang terhadap Undang-Undang Dasar ke Mahkamah Konsitusi. Oleh karena itu, sesungguhnya pekerjaan membentuk Undang-Undang bukanlah pekerjaan yang mudah, karena harus memahami makna yang terkandung di dalam Undang-Undang Dasar, baik di bagian pembukaan dan pasal-pasal dalam batang tubuh Undang-Undang Dasar.

Membentuk Undang-Undang, artinya membuat landasan operasional bagi penyelenggaraan kehidupan bernegara, membuat landasan berperilaku bagi seluruh bangsa Indonesia, sehingga diperlukan pemahaman yang sangat mendasar mengenai permasalahan, realitas yang ada atau dihadapi dalam kehidupan berbangsa dan bernegara. Memahami suatu permasalahan atau realitas yang ada pun bukan pekerjaan yang mudah, diperlukan metode penelitian yang tepat sehingga membawa pada pilihan penyelesaian yang juga tepat untuk permasalahan tersebut. Artinya, di dalam pembentukan UndangUndang, akan berbahaya sekali jika, pembentuknya memahami persoalan tidak secara mendasar karena akan memangkas lagi ide dan gagasan yang akan tertuang dalam bahasa teks peraturan perundang-undangan.

Penuangan norma hukum dalam peraturan perundang-undangan, menurut kajian ini tidak cukup dianggap selesai jika hanya mengandalkan pada teori jenjang norma Hans Kelsen secara formalitas. Maksudnya, norma yang lebih tinggi hanya digunakan sebagai dasar hukum mengingat saja tanpa memahami 
lebih jauh mengenai nilai atau teks bahasa dari pasal-pasal dalam batang tubuh UndangUndang Dasar. Terlebih jika hanya mengandalkan pada negosiasi untuk mencapai kesepakatan demi kepentingan politik yang perlu diakomodasi di dalam pembentukan Undang-Undang. Jika hanya ini yang dilakukan, maka norma hukum di dalam Undang-Undang akan collapse dan terisolasi ketika harus menyelesaikan masalah di masyarakat. Ini pun akan berbahaya jika Undang-Undang akan menjadi sumber dan dasar bagi pembentukan peraturan pelaksana dan peraturan otonom, bahkan sampai ke peraturan di tingkat daerah. Oleh karena itu sistem peraturan perundang-undangan yang dibentuk tidak mampu mendukung pembangunan sistem hukum nasional, bahkan hanya menyebabkan penumpukan regulasi yang tidak efektif dan efisien.

Diperlukan pemahaman makna dari suatu teks bahasa Undang-Undang Dasar untuk dapat mengadopsi nilai yang terkandung di dalamnya untuk diturunkan ke peraturan perundang-undangan yang lebih rendah. Misalnya saja, ada yang menawarkan dengan menggunakan hermeneutika. Melalui hermeneutik, kebenaran menjadi sesuatu yang harus ditemukan dan dicari untuk keadilan dan kemanfaatan hukum, meskipun itu tidak pernah final. Hermeneutika dianggap penting, karena norma dalam konteks Undang-Undang dianggap sebagai penentu dari nasib manusia di suatu negara. Melalui hermeneutika, pembentuk Undang-Undang dapat sampai ke perenungan lebih mendasar tentang apa artinya 'menafsir', apa resiko terjauhnya, dan faktor apa saja yang perlu diwaspadai di dalamnya (Puspitadewi, 2017).

Dengan demikian, memfungsikan Undang-Undang Dasar sebagai pembangun dari sistem hukum nasional, dalam hal ini ialah sistem peraturan perundang-undangan Indonesia menjadi penting agar pembentukan Undang-Undang tidak menemukan kesia-siaan dan mampu menurunkan nilai dari norma hukum yang lebih tinggi ke norma hukum yang lebih rendah. Efek dominonya yang diharapkan timbul ialah berkurangnya jumlah pengajuan judicial review atas UndangUndang terhadap Undang-Undang Dasar di Mahkamah Konstitusi.Artinya, memang dibutuhkan pemaknaan secara ideal dari fungsi Undang-Undang Dasar yang sesungguhnya, bahkan pendekatan filsafati dapat menjadi pilihan untuk dapat memahami makna yang terkandung dalam teks bahasa UndangUndang Dasar agar norma hukum yang dituangkan dalam Undang-Undang sebagai landasan operasional dapat pula berfungsi dengan baik sebagai salah satu sub sistem dari sistem hukum nasional.

\section{Simpulan}

Seharusnya Batang Tubuh UndangUndang Dasar tidak hanya difungsikan sebagai dasar hukum yang hanya dituliskan dalam butir Mengingat di dalam pembentukan Undang-Undang, melainkan diperlukan pemahaman makna dari suatu teks bahasa Undang-Undang Dasar untuk dapat mengadopsi nilai yang terkandung di dalamnya untuk diturunkan ke UndangUndang atau peraturan perundang-undangan yang lebih rendah. Misalnya saja, ada yang menawarkan dengan menggunakan hermeneutika. Pemahaman makna atas fungsi Undang-Undang Dasar sebagai aturan pokok yang mengatur tentang penyelenggaraan negara menjadi penting, karena pekerjaan membentuk Undang-Undang, artinya membuat landasan operasional bagi penyelenggaraan kehidupan bernegara, sebagai kelanjutan dari bunyi pasal-pasal Undang-Undang Dasar.Namun, memahami suatu permasalahan atau realitas yang ada pun bukan pekerjaan yang mudah, diperlukan metode penelitian yang tepat sehingga membawa pada pilihan penyelesaian yang juga tepat untuk permasalahan tersebut. Artinya, di dalam pembentukan UndangUndang, pembentuknya harus memahami persoalan secara mendasar agar mampu 
menuangkan ide dan gagasan dalam bahasa teks peraturan perundang-undangan. Penuangan norma hukum dalam peraturan perundang-undangan, menurut kajian ini tidak cukup dianggap selesai jika hanya mengandalkan pada teori jenjang norma Hans Kelsen secara formalitas. Terlebih jika hanya mengandalkan pada negosiasi untuk mencapai kesepakatan demi kepentingan politik yang perlu diakomodasi di dalam pembentukan Undang-Undang. Jika hanya ini yang dilakukan, maka norma hukum di dalam Undang-Undang akan terisolasi dan menemukan kesia-siaan serta gagal menurunkan nilai dari norma hukum yang lebih tinggi ke norma hukum yang lebih rendah.

\section{DAFTAR PUSTAKA}

Arief, Barda Nawawi. (2008). Kebijakan Hukum Pidana. Jakarta: Prenada Media Group.

Arief, Barda Nawawi. (2012). Pembangunan Sistem Hukum Nasional (Indonesia). Semarang: Pustaka Magister.

Danardono, Donny. (2015). Critical Legal Studies: Posisi Teori dan Kritik. Jurnal Ilmiah Hukum Kisi Hukum, pp. 1-6, p. 23.

Handayani, Yeni. (2014). Pengaturan Hak Asasi Manusia Dalam Konstitusi Indonesia dan Konstitusi Amerika Serikat. Jurnal Rechtvinding Online, Oktober 2014, pp. 1-9, p. 1-4.

Indrati, Maria Farida. (2007). Ilmu Perundang-undangan: Jenis, Fungsi dan Materi Muatan. Yogyakarta: Kanisius.
MD. Mahfud. (2010). Perdebatan Hukum Tata Negara Pasca Amandemen Konstitusi. Jakarta: Rajawali Press.

MD. Mahfud. (2012). Membangun Politik Hukum, Menegakkan Konstitusi. Jakarta: Rajawali Press.

Puspitadewi, Rachmani. (2017). Penerapan Hermeneutika Di Ranah Hukum. Bandung: Unpar Press.

Rahardjo, Satjipto. (1980). Hukum dan Masyarakat. Bandung: Angkasa.

Rohi, Sofia L. (2013). Implikasi UndangUndang Dasar 1945 Terhadap Sistem Perencanaan Pembangunan Nasional. Jurnal Politika. Volume 4. (Nomor 1, April), pp. 82-92, p. 82-83.

Rumokoy, Donald A. (2011). Praktik Konvensi Ketatanegaraan di Indonesia: Kajian Perbandingan di Inggris, Amerika Serikat, dan Belanda. Jakarta: Media Prima Aksara.

Santoso, M. Agus. (2013). Perkembangan Konstitusi Indonesia,Jurnal Yustisia, Volume 2. (Nomor 3, SeptemberDesember).

Sinamo, Nomensen. (2012). Hukum Tata Negara: Suatu Kajian Kritis Tentang Kelembagaan Negara. Jakarta: Permata Aksara.

Suhardjana, Johannes. (2010). Supremasi Konstitusi Adalah Tujuan Negara. Jurnal DinamikaHukum. Volume 10. (Nomor 3, September). pp. 257-269, p. 260

Yuliandri. (2013). Asas-Asas Pembentukan Peraturan Perundang-undangan Yang Baik: Gagasan Pembentukan UndangUndang Berkelanjutan. Jakarta: Rajawali Press. 